\title{
Skin Squamous Cell Carcinoma or Other Skin Carcinomas TNM Finding v7
}

National Cancer Institute

\section{Source}

National Cancer Institute. Skin Squamous Cell Carcinoma or Other Skin Carcinomas TNM

Finding v7. NCI Thesaurus. Code C88472.

A finding about one or more characteristics of skin squamous cell carcinoma or other nonmelanoma skin carcinomas excluding Merkel cell carcinoma, following the rules of the TNM AJCC v7 classification system. (from AJCC 7th Ed.) 